\section{Mosaic terminal del(19)(q13.33:) in a girl with seizures and mental retardation}

EDITOR-Constitutional deletions of chromosome 19 are very rare. ${ }^{1}$ At present, only one case of $19 \mathrm{p}$ deletion ${ }^{2}$ and six cases of a de novo proximal deletion of $19 q$ have been reported. The $19 \mathrm{q}$ deletions include an interstitial deletion $\operatorname{del}(19)(q 12 q 13.1)$ and a submicroscopic de novo deletion of $19 q 13$ resulting from $t(X ; 19)(p 21 ; q 13)$ in a patient with Diamond-Blackfan anaemia and congenital anomalies. ${ }^{34}$ The analysis of familial and sporadic cases of DiamondBlackfan anaemia showed four additional patients with de novo microdeletions that overlap the $19 \mathrm{q} 13.2$ region. ${ }^{5-7}$ No cases with a deletion of the terminal segment of $19 q$ have been described so far. We report the first case of a constitutional terminal mosaic deletion of $19 \mathrm{q}$ with a breakpoint at band $19 \mathrm{q} 13.33$.

The proband, a girl, was the result of the first pregnancy of healthy, unrelated, Estonian parents. At the child's birth, the mother was 20 and father 24 years old. The pregnancy was uneventful and the child was born at 42 weeks. Birth weight was $3920 \mathrm{~g}$, length $51 \mathrm{~cm}$, and head circumference (OFC) $35 \mathrm{~cm}$. She was asphyxiated at birth (Apgar score was 2 at five minutes) and required artificial ventilation for two hours. On the third day she had severe muscle spasticity (diplegia spastica II) and opisthotonos. At 1 year, spasticity of the muscles became progressively severe and her psychomotor development was delayed; she was not able to sit or stand. At the age of 10 years, she had severe mental retardation, absence of speech, and extremely severe spas- f Med Genet 2001;38 (http://jmedgenet.com/cgi/content/full/38/1/e2)

ticity of the muscles (tetraparesis spastica, ankylosis). Seizures began at the age of 21 years (once a week). Physical examination at the age of 25 years (fig 1) showed a girl with short stature $(130 \mathrm{~cm},<3$ rd centile) and microcephaly (OFC $52.5 \mathrm{~cm},<2$ nd centile), corresponding to the development of a 9 year old child. She was very thin with little subcutaneous fat. Minor anomalies included a low forehead, a beaked nose with hypoplastic nasal alae, a high palate, malocclusion of the teeth, and a transverse palmar crease on the left palm. The vertebral column was very deformed with lumbar lordosis and kyphoscoliosis. The lower extremities were deformed with flexion contractures of the knees. Secondary sex characteristics were undeveloped. The heart, urinary system, and other internal organs showed no congenital anomalies.

Chromosome analysis was done on cultured lymphocytes using GTG and RHG banding according to standard procedures. Fluorescence in situ hybridisation was performed with whole chromosome 19 painting probe (WCP 19) directly labelled with Spectrum Orange fluorophore (Vysis Inc, Downers Grove, IL, USA). To detect the chromosome specific subtelomeric regions, TelVysion DNA probes specific for $19 q$ directly labelled with Spectrum Orange ${ }^{\mathrm{TM}}$ fluorophore (Vysis Inc) were used. The parents were unavailable for chromosome analysis. Urinary amino acids and serum levels of TSH, T3, T4, cortisol, testosterone, progesterone, and oestradiol were measured by an Arcus fluorometer with DELFIA kits (Wallac, Turku, Finland).

Cytogenetic studies on cultured lymphocytes showed a mosaic deletion in the distal part of $19 q$ in $14 \%$ of the 300 metaphases studied. The breakpoint was at q13.33 (fig 2). FISH analysis with a WCP19 probe showed a signal only

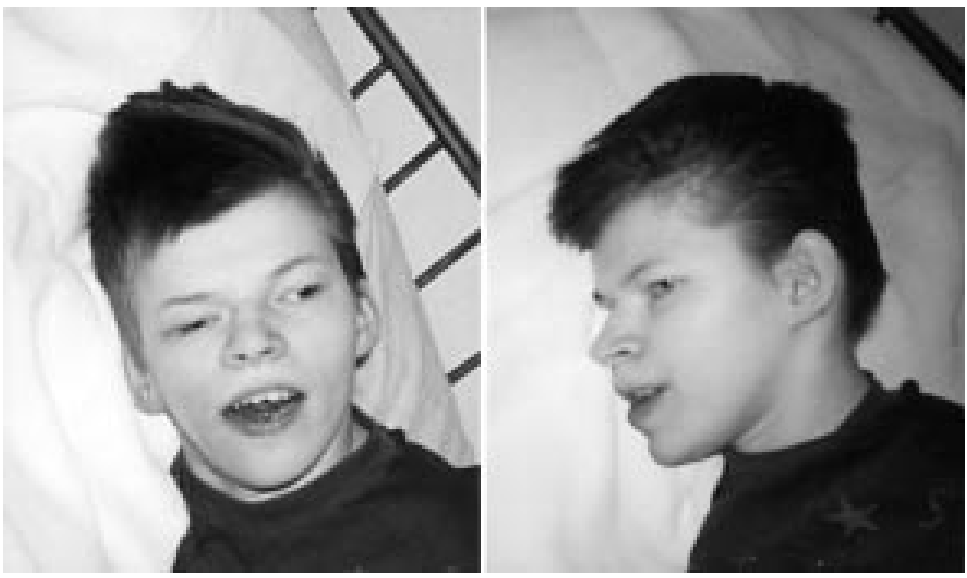

Figure 1 The proband aged 25 years.

GTG

RHG

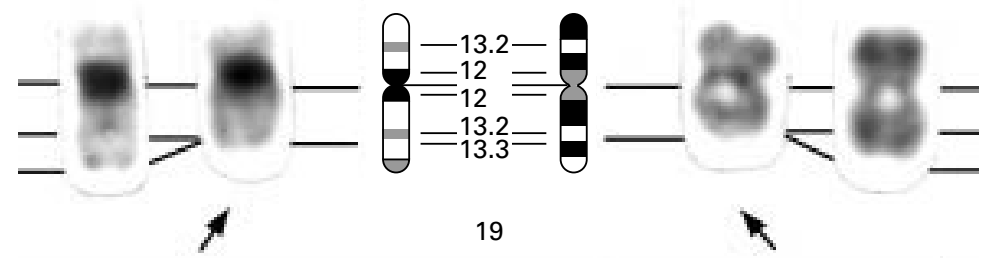

Figure 2 Partial karyotype of the proband showing GTG and RHG banding of normal and deleted chromosome 19 (arrowed). 

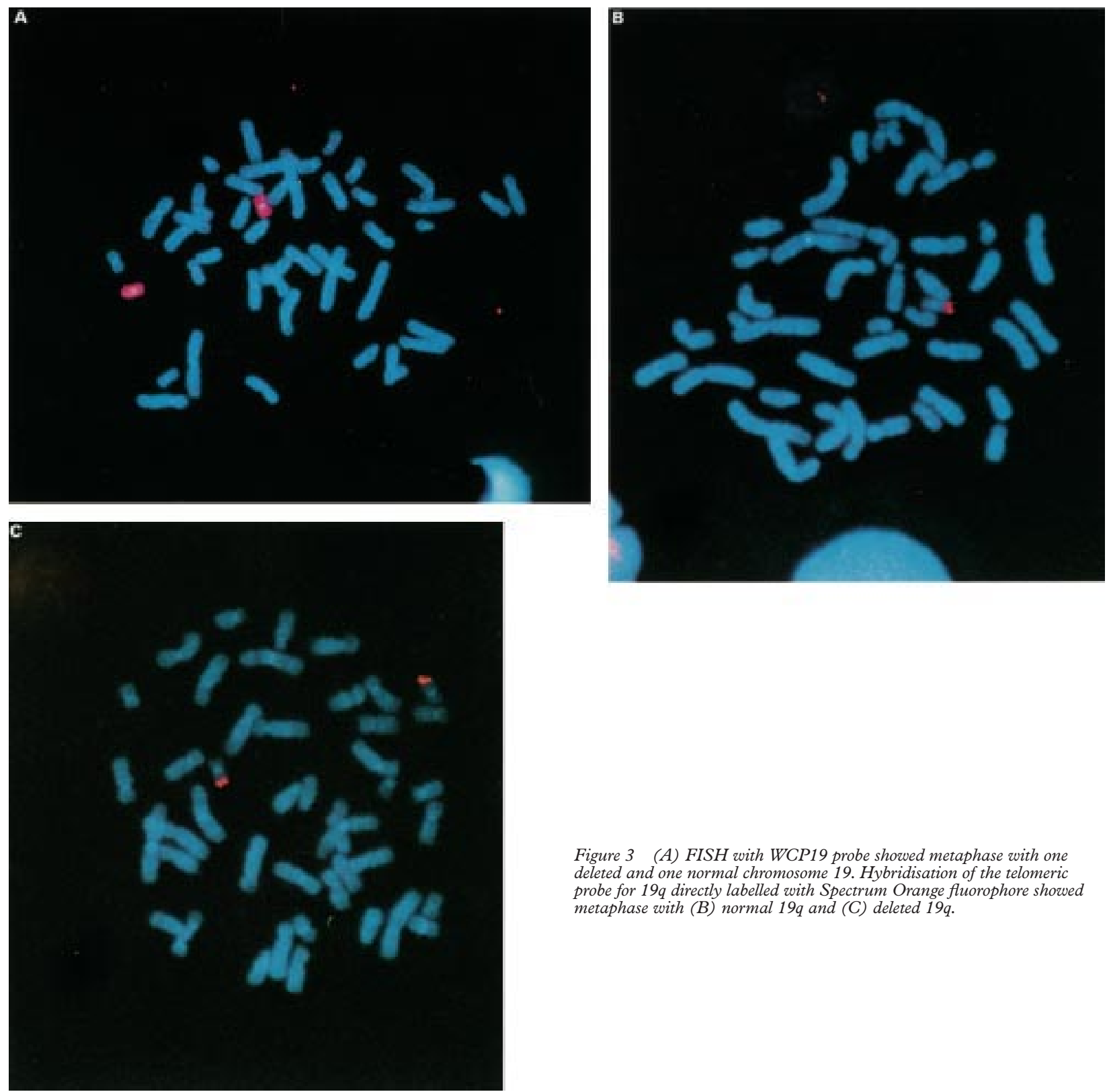

on the chromosome 19 and no other chromosomes (fig 3). Hybridisation of a telomeric probe specific for 19q gave one signal in the metaphases with a deleted chromosome 19 , while all other metaphases had two signals on the normal 19q. The proband's karyotype was interpreted as: mos 46,XX,del(19)(q13.33:)/46,XX.

Serum levels of hormones were normal, except for the decreased oestradiol level $(0.044 \mathrm{nmol} / \mathrm{l}$, normal range 0.1-2.0 nmol/1). Urinary amino acids were normal. Haematological examination showed no anaemia.

We describe the first case of terminal deletion for the region of $19 \mathrm{q} 13.33$-qter, it being the seventh one with a constitutional deletion of $19 \mathrm{q}$. The small number of cases of $19 q$ deletion reported so far may either be because of their rarity or early lethality. In our patient the longer survival was probably the result of the mosaicism of the deletion. The clinical features of our patient and the previously reported six cases of deletion $19 \mathrm{q}$ are not similar (table 1 ). This is probably because of the differences in the size and position of the deleted segments. Although a complete genotypephenotype correlation cannot be established in this patient, some genes mapped in $19 \mathrm{q}$ may help to explain the specific

features. The comparison of phenotypes in patients showed some common features, such as growth retardation, mental retardation, and skeletal anomalies of the long bones and spine. These features were described in most patients including four patients with both Diamond-Blackfan anaemia and deletion of $19 \mathrm{q} 13.2 .^{5-7}$ Absence of anaemia in our patient may confirm that the deleted segment is more distal to the Diamond-Blackfan anaemia critical gene region on $19 \mathrm{q} 13.2$. Growth retardation has many causes including deletion of the gene encoding transforming growth factor $\beta-1$ (TGFB1, 19q13.1-13.3). This patient and some of the other patients also have a high palate, strabismus, and little subcutaneous fat.

Our patient has a pattern of features that seem to be more specific to the deleted $19 \mathrm{q} 13.33$-qter region, such as a beaked nose, malocclusion of the teeth, transverse palmar crease, seizures, and absence of both anaemia and major congenital anomalies of the internal organs. The impact of the known genes which are hemizygously deleted in this patient (for example, carcinoembryonic antigen gene family) on the phenotype is unclear. Prepubertal external genitalia in our patient could be related to the decreased level 
Table 1 Clinical features in patients with $19 q$ deletions $^{3-7}$

\begin{tabular}{|c|c|c|c|c|c|c|c|}
\hline & $\begin{array}{l}\text { Case } 1 \\
\text { (q13) }\end{array}$ & $\begin{array}{l}\text { Case } 2 \\
(q 12 q 13.1)\end{array}$ & $\begin{array}{l}\text { Case } 3 \\
\text { (q13.2) }\end{array}$ & $\begin{array}{l}\text { Case } 4 \\
\text { (q13.2) }\end{array}$ & $\begin{array}{l}\text { Case } 5 \\
\text { (q13.2) }\end{array}$ & $\begin{array}{l}\text { Case 6 } \\
\text { (q13.2) }\end{array}$ & $\begin{array}{l}\text { Our proband } \\
(q 13.33 \rightarrow \text { qter })\end{array}$ \\
\hline Birth weight $(\mathrm{g})$ & 3400 & 1295 & & & & 2630 & 3920 \\
\hline Length $(\mathrm{cm})$ & & 40 & & & & 46 & 51 \\
\hline Head circumference $(\mathrm{cm})$ & & 27.5 & & & & 35 & 35 \\
\hline Gestation age (wk) & 40 & 38 & & & & 36 & 42 \\
\hline Growth retardation & + & + & & & & & + \\
\hline Psychomotor/mental retardation & & + & + & + & + & + & + \\
\hline Lack of subcutaneous fat & Fatigue & + & & & & - & + \\
\hline Microcephaly & & & & & & - & + \\
\hline Strabismus & & & & & & + & + \\
\hline Broad, tall forehead & & & & & & + & - \\
\hline Hypertelorism & & + & & & & + & - \\
\hline Beaked nose & & - & & & & - & + \\
\hline Malocclusion of teeth & & - & & & & & + \\
\hline High palate & & + & & & & & + \\
\hline Transverse palmar crease & & - & & & & & + \\
\hline $\begin{array}{l}\text { Skeletal anomalies } \\
\text { Long bones and spine }\end{array}$ & - & + & + & + & + & + & + \\
\hline Congenital deafness & & + & & & & & - \\
\hline Congenital heart defect & - & + & & & & & - \\
\hline Renal anomalies & + & + & & & & & - \\
\hline Anaemia & + & - & + & + & + & + & - \\
\hline Hypotonia & & + & & & & + & - \\
\hline Spasticity of muscles & & - & & & & - & + \\
\hline Seizures & & - & & & & & + \\
\hline Undeveloped sexual characteristics & & - & & & & & + \\
\hline Cryptorchidism & & & & & & + & \\
\hline
\end{tabular}

$+=$ present. $-=$ not present. Blank = unreported.

of oestradiol in serum. These clinical features might constitute a distinct $19 \mathrm{q}$ distal deletion syndrome.

We thank all the staff of Karula Homeschool for help in the management of patients. This study was supported by grant No 3025 from the Estonian Science Foundation.

\section{RUTH V MIKELSAAR ${ }^{\star}$
KADI VARB \\ ANNELI SÜVARI†} ALBERT SCHINZEL

*Department of Human Biology and Genetics, Institute of General and Molecular Pathology, University of Tartu, Ravila Street 19, Tartu 50411,

Estonia

†Homeschool of Karula, Estonia

$\ddagger$ Institute for Medical Genetics, University of Zürich, Switzerland

Correspondence to: Dr Mikelsaar, mikels@ut.ee

1 Borgaonkar DS. Chromosomal variation in man. 7th ed. New York: Wiley-Liss, 1994.
2 Hurgoiu V, Suciu S. Occurrence of $19 p$ - in an infant with multiple dysmorphic features. Ann Genet 1984;27:56-7.

3 Kulharya AS, Michaelis RC, Norris KS, Taylor HA, Garcia-Heras J. Constitutional del(19)(q12q13.1) in a three-year-old girl with severe phenotypic abnormalities affecting multiple organ systems. Am 7 Med Genet 1998;77:391-4.

4 Gustavsson P, Skeppner G, Johansson B, Berg T, Gordon L, Kreuger A, Dahl N. Diamond-Blackfan anaemia in a girl with a de novo balanced reciprocal X;19 translocation. $\mathcal{F}$ Med Genet 1997;34:779-82.

5 Gustavsson P, Willig TN, van Haeringen A, Tchernia G, Dianzani I, Donner M, Elinder G, Henter JI, Nilsson PG, Gordon L, Skeppner G, van't Veer-Korthof L, Kreuger A, Dahl N. Diamond-Blackfan anaemia: genetic homogeneity for a gene on chromosome $19 \mathrm{q} 13$ restricted to $1.8 \mathrm{Mb}$. Nat Genet 1997;16:368-71.

6 Gustavsson P, Garelli E, Draptchinskaia N, Ball S, Willig TN, Tentler D, Dianzani I, Punnett HH, Shafer FE, Cario H, Ramenghi U, Glomstein A, Pfeiffer RA, Goringe A, Olivieri NF, Smibert E, Tchernia G, Elinder G, Pfeiffer RA, Goringe A, Olivieri NF, Smibert E, Tchernia G, Elinder G,
Dahl N. Identification of microdeletions spanning the Diamond-Blackfan anemia locus on 19q13 and evidence for genetic heterogeneity. Am $\mathcal{F} \mathrm{Hum}$ anemia locus on $19 \mathrm{q} 13$ a

7 Cario H, Bode H, Gustavsson P, Dahl N, Kohne E. A microdeletion syndrome due to a 3-Mb deletion on 19q13.2 - Diamond-Blackfan anemia associated with macrocephaly, hypotonia, and psychomotor retardation. Clin Genet 1999;55:487-92 